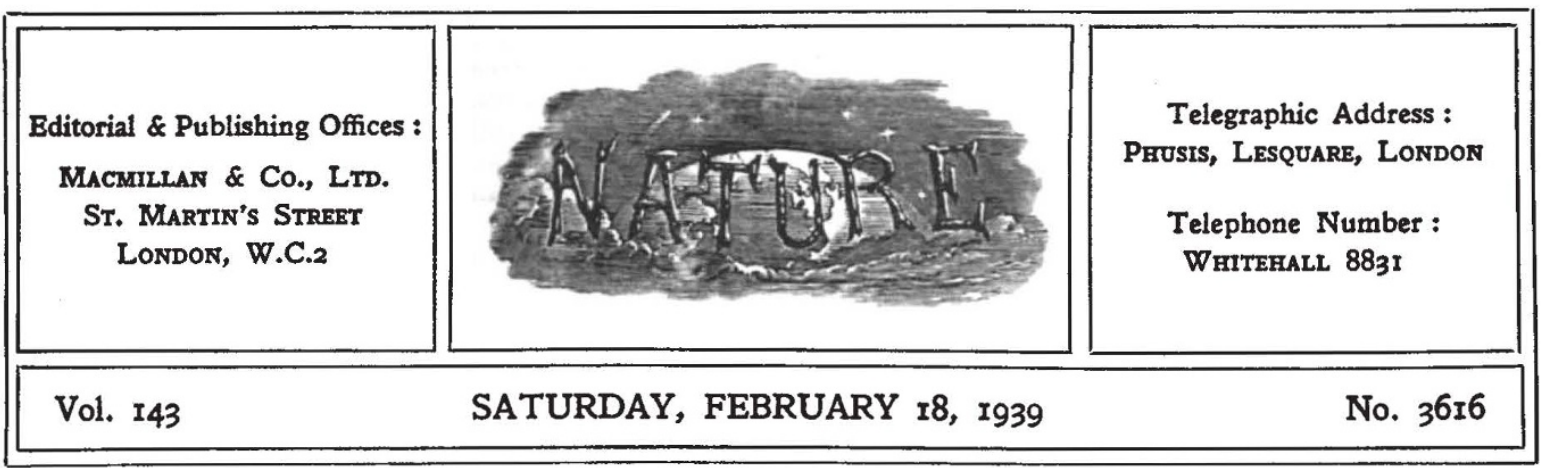

\title{
Science in Secondary Schools
}

SOCIAL organization is passing through a $S$ dynamic era. To-day the rate of change is higher, and, what is more important, we are more aware of it. For this reason the Spens report* is to be welcomed as a compendium of suggestions for meeting these changes, and above all as a clear statement that the duty of citizenship in a democracy renders it essential that all should be taught to understand and to think to the best of their ability. The report, the general trends of which were outlined in NATURE of January 21, p. 103, though of far-reaching importance, is perhaps not so revolutionary as was expected, which is all to the good ; for revolutionary changes, especially in such a highly organized system as that of education, would only result in confusion and counter-revolution. There is, after all, only a difference of degree between the pronouncements of Arnold and Sanderson, and those of such present-day educationists as Sir Richard Gregory, who once defined education as "the deliberate adjustment of a growing human organism to its environment". Furthermore, several of even the more important suggestions set forth in the Spens report are not new, but have. already been made by other authoritative bodies. This illustrates the broad outlook and the democratic spirit adopted by the Spens Committee and the large body of witnesses which helped it in its deliberations.

Though the curriculum, it is considered, should have more regard to the vocational future of pupils rather than give so much time to training potential university students, a good general education is recommended. Thus does the report re-emphasize

- Report of the Consultative Committee on Secondary Fducation wth Special Beference to Grammar Schools and Technical High schools. Pp. Xxvili +475. (London: H.M. Stationery Office, 1939.) 88. 6d. net. the recommendations made earlier by the Hadow, Malcolm and Goodenough Committees. It is not suggested, however, that education has been virtually at a standstill since these recommendations were made. Much progress has indeed been made.

The teaching of science in secondary schools is subjected to much constructive criticism in the report. A plea is put forward for a more intimate alliance between subjects, provided the essential autonomy of each is preserved. It is clear, too, that certain scientific subjects are needlessly subdivided. Advantage should also be taken of the inherent curiosity of children about the practical concerns and activities of the world to bring their studies into closer contact with the practical affairs of life. This is best done by making the curriculum more general and freer, and most will agree with Dr. H. A. L. Fisher that is all to the good. The Spens Committee is thus led to urge strongly the claims of general science to a place in secondary school education.

The Committee considers that the teaching of science has lost touch with life itself, and for this reason has often failed either to give knowledge required or to stimulate the pupils' interest. This supports the pleas made by Sir William Bragg, in his presidential address to the Science Masters' Association in 1936, for the teaching of science in ways that will facilitate co-operation in dealing with national and international affairsa strong plea in face of the present-day challenge to democracy.

There can be little doubt that in the early educative period more generalized science teaching is required. 'This was agreed so far back as 1934 at a conference arranged by the Science Masters' 
Association and the Institute of Education of the University of London. There the inclusion of biology in the syllabus was urged, which led Prof. E. N. da C. Andrade to admit that such a wider syllabus might lead to some superficiality of treatment, but he could see no particular harm in that-a statement of greater significance perhaps now than then. The interim report of the subcommittee appointed by the Science Masters' Association to consider the question of general science was much in favour of teaching the subject, and we commented (see NATURE, 138, $1030 ; 1936$ ) on the efforts being made to change school science from its traditional, intensive and formal habit to a broader and more human shape. The addition of biology to a curriculum hitherto containing physics and chemistry only must of necessity broaden the cultural aims of science teaching. A general syllabus containing all three subjects aims, as no narrower syllabus can, at helping the pupil towards an intelligent understanding of his immediate environment, and thus forms a sounder basis for widening his interests and understanding in later life.

The Spens report emphasizes all this very thoroughly, and goes so far as to say that, in boys' schools especially, science teaching is too often restricted to the physical sciences, and in girls' schools too much botany is taught at the expense of biology. It is, therefore, of interest to compare the number of candidates in England and Wales offering these subjects in the School Certificate examinations in 1933 with those of 1937. In 1933, 27,007 candidates offered chemistry ; in 1937, the number was 27,246-a negligible increase; physics has shown an increase from 18,860 to 20,826 ; botany a decrease from 13,094 to 8,487 ; biology an increase from 6,171 to 15,119 ; and general science an increase from 2,560 to 4,779 . Although the period taken is comparatively short, it seems, therefore, that the recommendations made by various bodies in the past few years are bearing fruit. So this augurs well for the Spens report.

The report goes still further, however, in its recommendation that science should be more generalized. It suggests that astronomy and possibly some geology should be included; while in chemistry, a certain amount of attention should be given to organic studies. There seems no sound argument against such recommendations, which should have the whole-hearted support of every educationist and man of science. It is interesting to note, too, that the final report of the sub-committee of the Science Masters' Association*, recently issued, puts forward similar views.

The Spens report gives special consideration to the peculiar problems of the country secondary schools, asserting that full advantage should be taken of their rural environment. The report recommends the teaching of more biology, agriculture, gardening and so forth, and the application of local surveys and farm statistics to geography and mathematics. The special position of a rural school is so obvious that to take advantage of the resources of the countryside seems a natural sequence. As optional subjects, the final report of the Science Masters' Association also recom. mends more biology, ecology, gardening and agriculture. While agreeing in principle with these conclusions, we suggest that they be treated with a certain amount of caution. The immediate environment of the rural school is naturally an advantage and convenience for the teacher. But more important than this is consideration for the future of the taught. Carried to ill-considered extremes, these recommendations would involve a 'rural population' receiving a rural education, and an 'urban population' a non-rural education. But there are children in the country more talented in the physical sciences, and the reverse applies to certain town children. Physics, chemistry and astronomy can and should be taught equally in both types of school; and in the town school, experimental biology can be taught, though of course not with such a wealth of material at hand as in the rural school. Few town children of to-day are absolutely unfamiliar with country life, or at any rate with plant and animal life, including man. While supporting the suggestion, therefore, that the school should take advantage of its environment, we would plead for a certain balance and plasticity in the individual school curriculum, in order to prevent the production of a certain number of 'square pegs in round holes'.

As we have stated over and over again, the narrowness of school science is due in no mean measure to the stranglehold of examinations. This applies especially to the School Certificate examination, which is the subject of criticism in the Spens and Science Masters' Association reports. At present, it tends to enforce an undesirable

" "The Teaching of General Science". Part 2. The Science Masters" Association. (London: John Murray, 1938). 2s. 6d. 
uniformity in the curriculum, especially through its group system. The abolition of this grouping was recommended by the Secondary Schools Examination Council (Circular 1463, H.M. Stationery Office). This is now endorsed by the Spens Committee, and certain examining bodies have decided to adopt the recommendation. Such a recommendation will relieve the pupil from forced issues and encourage him more to follow his own bent. It is, for this reason, to be hoped that the recommendation will eventually be adopted by all examining bodies. Furthermore, both reports plead for a consideration of school records supplied by those who have taught the candidates. We welcome this suggestion, since it would relieve the examiners of what is tantamount to absolute authority in assessing educational merit, for which everyone, and especially the examiners themselves, would feel grateful.

It is gratifying to note that in the House of Commons on February 2, the Parliamentary Secretary to the Board of Education stated, in reply to a question, that the Spens report is being examined departmentally, and that "no time will be lost in getting into touch with local education authorities and other interested parties for the purpose of a full discussion of the important and constructive recommendations on such matters, among others, as technical high schools, the curriculum of grammar schools, the school certificate examination, and the inspection of private schools".

The recommendations enumerated above, even if only adopted in part, are bound to have their repercussions on the teacher as well as on the pupil. This is an important aspect of the problem which the Science Masters' Association report seems to have taken more to heart than has the Spens report. It is axiomatic that the right kind of teacher is required-one with a 'generous' training in science rather than the narrow specialist. Many teachers in secondary schools are university graduates who have specialized in one or two subjects. They would naturally feel embarrassed on being asked to teach subjects with which they are not familiar. In fact, according to the Science Masters' Association report, some of them are not in favour of general science for this reason. But that is merely shelving the problem. In any event, there is, as stated in this report, a tendency to exaggerate the difficulty, and the same report offers suggestions to such specialized teachers. There are, for example, Board of Education studentships to enable teachers to improve their qualifications, university diplomas in certain subjects, evening courses in universities and colleges, vacation courses and so forth. There are also other facilities ; for example, the Educational Advisory Board of the British Social Hygiene Council is offering a course for teachers in biology.

But these, at their best, can only help presentday teachers, and not even all those. It is the teacher of the future who will have to face the problem in its entirety. It is, therefore, the responsibility of the authorities to see that the most suitable teachers are available to deal with changes in educational curricula and methods. Most committees dealing with the problem look solely to the universities for aid and inspiration. But it is not the main function of a university to produce school teachars, although one cannot justifiably accuse them of being blind to the needs of the teaching profession. Much could be done before the future teacher makes his final choice of degree work. It is difficult, for example, to see the necessity for so many honours graduates in schools. A teacher with a general degree has, at any rate, sufficient actual knowledge of his subjects for school-teaching purposes, and more of them.

It is, we think, to the training colleges and education departments of the universities from which help might also be expected. Certain of them are already making efforts to produce the kind of teacher required to meet the changes in educational method. The education department of the University of Reading, for example, already offers a course on the teaching of rural science to graduates in science, agriculture and horticulture (see p. 305). This policy could, we think, with advantage be extended in such training institutions to the teaching of general science. Many student teachers enter their period of teacher-training either concurrently with their reading for a degree or after having graduated. They have already, therefore, a certain knowledge of scientific method and outlook, and should be easy material for elementary instruction in other scientific subjects and in general scientific methods. In this way, teachers with the requisite knowledge of general science could be supplied to the schools - teachers infinitely better equipped to teach general science than the first-class honours man who, in order to teach it competently, is forced to devote his spare time to extra courses of instruction after his period of training. 